\title{
Influence of the Material State of Ground, Case-Hardened Steels on the Barkhausen Noise Depending on the Surface Integrity*
}

\author{
Einfluss des Werkstoffzustands geschliffener, einsatzge- \\ härteter Stähle auf das Barkhausenrauschen in Abhängig- \\ keit der thermo-mechanischen Randzonenbeeinflussung
}

The manufacturing process of grinding generally leads to a thermo-mechanical influence on the surface integrity. In addition to the intended development of residual compressive stresses due to the finishing process, disturbances in the grinding process can lead to negative effects such as tensile residual stresses, tempering and even rehardening zones and significantly reduce the component lifetime. In industrial applications, the analysis of Barkhausen noise is becoming increasingly important for the detection of this unwanted thermo-mechanically influenced surface integrity. The non-destructive method reacts sensitively to changes in, for example, the residual stress state as well as the hardness. In addition, other material-, process- and metrology-related influences are described in literature. The investigations presented in this paper deal with the influence of different material states (case-hardening depth, surface carbon content and alloy composition) on the signals of the Barkhausen noise as a function of the surface integrity. It is shown that the signal level is significantly influenced by the material condition and thus individual limit values must be used for evaluation of the surface integrity.

Keywords: Grinding burn, surface integrity, grinding, Barkhausen noise, AISI 4820 (18CrNiMo7-6)

Das Fertigungsverfahren Schleifen führt grundsätzlich zu einer thermo-mechanischen Beeinflussung der Werkstückrandzone. Neben der erwünschten Ausprägung von Druckeigenspannungen durch den Schlichtprozess können Störungen im Schleifprozess zu einer negativen Beeinflussung in Form von Zugeigenspannungen und Anlasszonen bis hin zu Neuhärtungszonen führen und die Bauteillebensdauer erheblich reduzieren. In der industriellen Anwendung kommt der Analyse des Barkhausenrauschens eine zunehmende Bedeutung zur Detektion dieser unerwünschten thermo-mechanischen Randzonenbeeinflussungen zu. Das zerstörungsfrei arbeitende Verfahren reagiert beispielsweise sensibel auf Änderungen des Eigenspannungszustands sowie der Härte. Daneben sind weitere werkstoff-, prozess- und verfahrenstechnische Einflüsse in der Literatur beschrieben. Die in diesem Beitrag vorgestellten Untersuchungen beschäftigen sich mit dem Einfluss unterschiedlicher Werkstoffzustände (Einhärtetiefe, Randkohlenstoffgehalt und Legierungszusammensetzung) auf die Signale des Barkhausenrauschens in Abhängigkeit des Randzonenzustands. Es wird gezeigt, dass die Signalhöhe maßgeblich durch den Werkstoffzustand beeinflusst wird und damit individuelle Grenzkriterien zur Bewertung des Randzonenzustands zu Grunde gelegt werden müssen.

Schlïsselwörter: Schleifbrand, Randzonenzustand, Schleifen, Barkhausenrauschen, $18 \mathrm{CrNiMo7}-6$

Authors/Autoren: Dr.-Ing. Daniel Sackmann, M.Sc. Jonas Heinzel, Prof. Dr.-Ing. habil. Prof. h.c. Dr. h.c. Dr. h.c. Bernhard Karpuschewski, Leibniz-Institut für Werkstofforientierte Technologien - IWT, Badgasteiner Str. 3, Bremen, 28359, Deutschland, sackmann@iwt-bremen.de (corresponding author/Kontakt)

HOW TO CITE THIS ARTICLE: D. Sackmann et al.: Influence of the Material State of Ground, Case-Hardened Steels on the Barkhausen Noise Depending on the Surface Integrity. HTM J. Heat Treatm. Mat. 76 (2021) 1, pp. 5-18, DOI:10.1515/htm-2020-0001

* Lecture held at the HeatTreatingCongress, HK, October 22-24, 2019 in Cologne, Germany 


\section{Introduction}

Components from the field of drive technology underlie strict requirements regarding shape and dimensional tolerance as well as surface quality. For this reason, hard finishing by grinding is usually applied after heat treatment as last process step in the value-added chain in order to remove hardening distortions or scaling on functional surfaces $[1,2]$. Grinding is generally accompanied by a thermo-mechanical influence on the surface integrity, whereby the surface properties resulting from the grinding process in turn co-determine the functional behavior of the workpiece. Disturbances within the grinding process, for example due to an insufficient supply of cooling lubricant, fluctuations in allowance, an unsuitable choice of process parameters or a deviating microstructure composition, can lead to thermo-mechanical damages of the workpiece surface. Depending on the degree of damage, different effects occur, which are summarized under the term grinding burn. These effects emerge in the form of tensile stresses at or below the surface as well as the formation of tempering or rehardening zones up to the occurrence of grinding cracks $[3,4]$. In addition to temper etching, which is well established in the industry, micromagnetic analysis of Barkhausen noise is considered to have a high potential for detecting these undesirable modification of the surface integrity [5].

The non-destructive analysis of the Barkhausen noise is based on magnetization of ferromagnetic materials by an externally applied alternating magnetic field. The magnetization of the test component occurs unsteadily due to physical mechanisms and can be measured with the aid of an appropriate sensor in the form of a noise-like voltage signal, the Barkhausen noise [5, 6]. The Barkhausen noise is determined by a number of material-, process- and metrology-specific influencing factors. On the material side, the influence of the microstructure in the form of grain size and orientation as well as the dislocation density and precipitations of different types are mentioned in particular [4, 6-9]. Varying heat treatment parameters to achieve different target values with respect to the hardening depth or the surface carbon content influence the Barkhausen noise for their part [10,11]. On the process engineering side, influences due to the thermo-mechanical load during contact between the workpiece and the grinding tool should be mentioned above all. This influences, for example, the residual stress state in the surface near area and, with correspondingly high loads, leads to changes in microstructure and hardness $[5,8,9,12-14]$. From the metrology engineering side, the Barkhausen noise is mainly influenced by the magnetization and analyzing frequencies, which affect the interaction and analyzing depth, respectively. [15-19].

In the presented investigations, the influence of different material states in terms of case-hardening depth, surface content and alloy composition on the RMS-value, the root mean square and standard parameter of the Barkhausen noise, is evaluated in detail as a function of the surface integrity. For this purpose, cylindrical

\section{Einleitung}

Bauteile aus dem Bereich der Antriebstechnik unterliegen strengen Anforderungen hinsichtlich der Form- und Maßtoleranz sowie der Oberflächengüte. Aus diesem Grund wird nach der Wärmebehandlung in der Regel eine Hartfeinbearbeitung mittels Schleifen als letzter Prozessschritt in der Wertschöpfungskette durchgeführt, um unter anderem Härteverzüge oder Verzunderungen an den Funktionsflächen zu entfernen [1, 2]. Das Schleifen geht generell mit einer thermo-mechanischen Beeinflussung der Werkstückrandzone einher, wobei die aus der Schleifbearbeitung resultierenden Randzoneneigenschaften ihrerseits das Bauteilfunktionsverhalten mitbestimmen. Störungen im Schleifprozess, zum Beispiel durch eine unzureichende Kühlschmierstoffzufuhr, Aufmaßschwankungen, eine ungeeignete Wahl der Prozessstellgrößen oder eine abweichende Gefügezusammensetzung können dabei zu thermo-mechanischen Randzonenschädigungen führen. Je nach Ausprägung treten dabei unterschiedliche Effekte, die unter dem Begriff Schleifbrand zusammengefasst werden, auf. Diese äußern sich in Form von Zugspannungen an bzw. unterhalb der Oberfläche sowie der Ausbildung von Anlass- bzw. Neuhärtungszonen bis hin zum Auftreten von Schleifrissen [3, 4]. Neben der in der Industrie etablierten Nitalätzung wird der mikromagnetischen Analyse des Barkhausenrauschens ein hohes Potential zur Detektion dieser unerwünschten Randzonenbeeinflussungen zugeschrieben [5].

Die zerstörungsfreie Analyse des Barkhausenrauschens basiert auf einer Magnetisierung ferromagnetischer Werkstoffe durch ein von außen anliegendes Wechselmagnetfeld. Die Magnetisierung des Prüfbauteils findet aufgrund physikalischer Mechanismen sprungartig statt und ist mithilfe der entsprechenden Sensorik in Form eines rauschartigen Spannungssignals, dem Barkhausenrauschen, messbar $[5,6]$. Das Barkhausenrauschen wird durch eine Reihe an werkstoff-, verfahrens- und prozessspezifischer Einflussfaktoren bestimmt. So wird auf werkstofftechnischer Seite insbesondere der Einfluss der Gefügemikrostruktur in Form der Korngröße und -orientierung sowie der Versetzungsdichte und Ausscheidungen unterschiedlicher Art genannt [4, 6-9]. Variierende Wärmebehandlungsparameter zur Erreichung unterschiedlicher Zielwerte hinsichtlich der Einhärtetiefe oder des Randkohlenstoffgehalts beeinflussen das Barkhausenrauschen $[10,11]$. Auf prozesstechnischer Seite sind vor allem Einflüsse durch die thermo-mechanische Belastung beim Kontakt zwischen Werkstück und Werkzeug zu nennen. Diese beeinflussen beispielsweise den Eigenspannungszustand in der Randzone und führen bei entsprechend hoher Belastung zu Gefüge- und Härteveränderungen $[5,8,9,12-14]$. Von verfahrenstechnischer Seite wird das Barkhausenrauschen vor allem durch die Magnetisierungs- und Analysierfrequenzen, die sich auf die Wechselwirkungs- und Analysiertiefe auswirken, bestimmt [15-19].

In den vorgestellten Untersuchungen wird der Einfluss unterschiedlicher Werkstoffzustände hinsichtlich Einhärtetiefe, Randkohlenstoffgehalt und Legierungszusammensetzung auf den RMS-Wert, dem zeitlichen quadratischen Mittelwert und Standardparameter des Barkhausenrauschens, in Abhängigkeit vom 
round workpieces are machined by means of outer diameter grinding under variation of the specific material removal rate $\mathrm{Q}_{\mathrm{w}}$ and different surface conditions up to the occurrence of strong tempering zones are generated. The resulting surface properties are characterized to evaluate the surface integrity. This is followed by an analysis of the Barkhausen noise. Finally, an evaluation of the influence on the RMS-value due to the material state is done.

\section{Test setup and procedure}

The investigations were carried out on cylindrical, differently case-hardened workpieces made of the material AISI 4820 (18CrNiMo7-6) with a hardness of 58 HRC. The workpieces were gas carburized and quenched in oil. The surface carbon content and the case-hardening depth were varied in two steps according to Table 1. In order to be able to describe an alloy influence, the heat treatment was carried out on two material batches, BGH and DEW, which means a total of eight material states result for the test program. The composition of both material batches is shown in Table 2. When selecting the batches, it was ensured that both of them show different hardenabilities.

In order to ensure a clear classification, the different material states will be marked with the following notation in the further course:

Material batch_case-hardening depth_surface carbon content

The material state BGH_1.0_0.6 thus describes a workpiece of material batch BGH with a hardening depth of $1.0 \mathrm{~mm}$ and a surface carbon content of $0.6 \mathrm{wt} .-\%$.

Table 3 lists the values of the process parameter set during heat treatment (holding period $t$, temperature $\mathrm{T}$ and carbon level $c_{\mathrm{p}}$ ) in order to to achieve the target values of each material state. A mixture of nitrogen and methanol, to which propane was added to regulate the carbon level, was used as the carburizing medium. Before quenching, the temperature was reduced to $\mathrm{T}=850^{\circ} \mathrm{C}$. After case hardening, the workpieces were tempered for two hours in an air-circulation furnace at $180^{\circ} \mathrm{C}$.

\begin{tabular}{|c|c|c|}
\hline Parameter & Zielwert I & Zielwert II \\
\hline Randkohlenstoffgehalt $c_{R}$ & $0,6 \mathrm{~m} \%$ & $0,8 \mathrm{~m} \%$ \\
\hline Einhärtetiefe EHT & $1,0 \mathrm{~mm}$ & $2,2 \mathrm{~mm}$ \\
\hline
\end{tabular}

\begin{tabular}{|c|c|c|c|c|c|c|}
\hline Charge & $\mathrm{C}[\mathrm{m} \%]$ & $\begin{array}{c}\mathrm{Si} \\
{[\mathrm{m} \%]}\end{array}$ & $\begin{array}{c}\mathrm{Mn} \\
{[\mathrm{m} \%]}\end{array}$ & $\begin{array}{c}\mathrm{Cr} \\
{[\mathrm{m} \%]}\end{array}$ & $\begin{array}{c}\mathrm{Mo} \\
{[\mathrm{m} \%]}\end{array}$ & $\begin{array}{c}\mathrm{Ni} \\
{[\mathrm{m} \%]}\end{array}$ \\
\hline BGH & 0,19 & 0,28 & 0,52 & 1,61 & 0,27 & 1,53 \\
\hline DEW & 0,18 & 0,22 & 0,61 & 1,48 & 0,25 & 1,49 \\
\hline
\end{tabular}

Table 2. Chemical composition of the two material batches $\mathrm{BGH}$ and DEW

Tabelle 2. Chemische Zusammensetzung der beiden Materialchargen $\mathrm{BGH}$ und DEW

Randzonenzustand, eingehend evaluiert. Dazu werden zylindrische Rundproben mittels Außenrund-Umfangs-Querschleifen unter Variation des bezogenen Zeitspanvolumens $\mathrm{Q}_{\mathrm{w}}$ bearbeitet und unterschiedliche Randzonenzustände bis hin zum Auftreten starker Anlasszonen generiert. Die resultierenden Randzoneneigenschaften werden charakterisiert, um die Randzonenbeeinflussung zu quantifizieren. Es folgt eine Analyse des Barkhausenrauschens. Abschließend findet eine Einflussbewertung des Werkstoffzustands auf den RMS-Wert statt.

\section{Versuchsaufbau und -durchführung}

Die Untersuchungen wurden an zylindrischen, unterschiedlich einsatzgehärteten Werkstücken aus dem Werkstoff 18CrNiMo7-6 mit einer Härte von 58 HRC durchgeführt. Die Werkstücke wurden gasaufgekohlt und in Öl abgeschreckt. Dabei wurden der Randkohlenstoffgehalt und die Einhärtetiefe jeweils zweistufig entsprechend Tabelle 1 variiert. Um einen Legierungseinfluss abbilden zu können, wurde die Wärmebehandlung jeweils an den beiden Materialchargen BGH und DEW durchgeführt, sodass sich insgesamt acht Werkstoffzustände für das Versuchsprogramm ergeben. Die Zusammensetzung beider Materialchargen ist in Tabelle 2 dargestellt. Bei der Chargenauswahl wurde darauf geachtet, dass beide Chargen unterschiedliche Härtbarkeiten aufweisen.

Um eine eindeutige Zuordnung zu gewährleisten, werden die unterschiedlichen Werkstoffzustände im weiteren Verlauf mit folgender Notation gekennzeichnet:

\section{Materialcharge_Einhärtetiefe_Randkohlenstoffgehalt}

Der Werkstoffzustand BGH_1,0_0,6 beschreibt demnach ein Werkstück der Materialcharge BGH mit einer Einhärtetiefe von $1,0 \mathrm{~mm}$ und einem Randkohlenstoffgehalt von $0,6 \mathrm{~m} \%$.

In Tabelle 3 sind die zur Erreichung der Zielwerte eingestellten Werte der Prozessstellgrößen während der Wärmebehandlung (Haltedauer t, Temperatur T und Kohlenstoffpegel $c_{p}$ ) aufgeführt. Als Aufkohlmedium wurde ein Gemisch aus Stickstoff und Methanol eingesetzt, dem Propan zur Regulierung des Kohlenstoffpegels zugefügt wurde. Vor dem Abschrecken wurde die Temperatur auf $\mathrm{T}=850^{\circ} \mathrm{C}$ reduziert. Nach dem Einsatzhärten wurden die Werkstücke für zwei Stunden bei $180^{\circ} \mathrm{C}$ in einem Luftumwälzofen angelassen.

Table 1. Target values of heat treatment

Tabelle 1. Zielwerte der Wärmebehandlung 
Table 3. Variation of the process parameters during heat treatment: holding period $t$, temperature $T$ and carbon level $c_{p}$

Tabelle 3. Variation der Prozessstellgrößen während derWärmebehandlung: Haltedauer t, Temperatur T und Kohlenstoffpegel $c_{p}$

\begin{tabular}{|c|c|c|c|c|}
\hline & $\begin{array}{c}\text { BGH/DEW } \\
1,0 \_0,6 \\
\end{array}$ & $\begin{array}{c}\text { BGH/DEW } \\
1,0 \_0,8 \\
\end{array}$ & $\begin{array}{c}\text { BGH/DEW } \\
2,2 \_0,6 \\
\end{array}$ & $\begin{array}{c}\text { BGH/DEW } \\
2,2 \_0,8\end{array}$ \\
\hline \multirow{3}{*}{ ت } & $120 \mathrm{~min}$ & $120 \mathrm{~min}$ & $120 \mathrm{~min}$ & $120 \mathrm{~min}$ \\
\hline & $850^{\circ} \mathrm{C}$ & $850^{\circ} \mathrm{C}$ & $850^{\circ} \mathrm{C}$ & $850^{\circ} \mathrm{C}$ \\
\hline & $0,6 \%$ & $0,6 \%$ & $0,6 \%$ & $0,6 \%$ \\
\hline \multicolumn{5}{|c|}{ Aufheizen auf $940^{\circ} \mathrm{C}$} \\
\hline \multirow{3}{*}{ 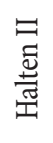 } & $140 \mathrm{~min}$ & $120 \mathrm{~min}$ & $660 \mathrm{~min}$ & $840 \mathrm{~min}$ \\
\hline & $940^{\circ} \mathrm{C}$ & $940^{\circ} \mathrm{C}$ & $940^{\circ} \mathrm{C}$ & $940^{\circ} \mathrm{C}$ \\
\hline & $1,05 \%$ & $1,05 \%$ & $1,05 \%$ & $1,05 \%$ \\
\hline \multirow{3}{*}{ 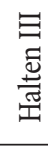 } & $30 \mathrm{~min}$ & $60 \mathrm{~min}$ & $360 \mathrm{~min}$ & $120 \mathrm{~min}$ \\
\hline & $940^{\circ} \mathrm{C}$ & $940^{\circ} \mathrm{C}$ & $940^{\circ} \mathrm{C}$ & $940^{\circ} \mathrm{C}$ \\
\hline & $0,55 \%$ & $0,75 \%$ & $0,54 \%$ & $0,73 \%$ \\
\hline \multicolumn{5}{|c|}{ Abkühlen auf $850^{\circ} \mathrm{C}$} \\
\hline \multirow{3}{*}{ 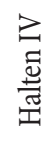 } & $120 \mathrm{~min}$ & $120 \mathrm{~min}$ & $120 \mathrm{~min}$ & $120 \mathrm{~min}$ \\
\hline & $840^{\circ} \mathrm{C}$ & $840^{\circ} \mathrm{C}$ & $840^{\circ} \mathrm{C}$ & $840^{\circ} \mathrm{C}$ \\
\hline & $0,54 \%$ & $0,74 \S$ & $0,54 \%$ & $0,72 \%$ \\
\hline \multicolumn{5}{|c|}{ Abschrecken in Durixol W72 $\left(60^{\circ} \mathrm{C}\right)$} \\
\hline
\end{tabular}

Durch eine nachfolgende metallografische Analytik konnte bestätigt werden, dass die Zielwerte erreicht wurden. $\mathrm{Zu}$ diesem Zweck wurden Härtemessungen nach Vickers (Härtetiefenverläufe) durchgeführt und mittels optischer Emissionsspektroskopie Kohlenstofftiefenprofile ermittelt. Zudem wurden Gefügeschliffe angefertigt.

Jedes Werkstück wird durch sieben Segmente charakterisiert, die individuell voneinander mittels Außenrund-Umfangs-Querschleifen bearbeitet wurden (vgl. Bild 1). Für die Schleifbearbeitung wurde eine Universal-Rundschleifmaschine des Typs Studer S41 in Kombination mit einer Korundschleifscheibe des Typs Tyrolit A80CC5V eingesetzt. Der Versuchsaufbau ist ebenfalls in Bild 1 dargestellt.

Die während der Schleifbearbeitung auftretenden Prozesskräfte wurden mithilfe zweier in der Werkzeugmaschine integrierter Kraftmesssysteme ermittelt. Beide Systeme sind aus jeweils vier piezoelektrischen 3-Komponenten Kraftsensoren der Kistler Instrumente GmbH (Typ 9067C) aufgebaut und wurden am Leibniz-IWT entwickelt.
The process forces occurring during grinding were determined with the aid of two force measurement systems integrated in the machine tool. Both systems consist of four piezoelectric 3-component force sensors from Kistler Instrumente GmbH (type 9067C) and were developed at Leibniz-IWT.
Fig. 1. Workpiece and experimental setup

Bild 1. Werkstück und Versuchsaufbau

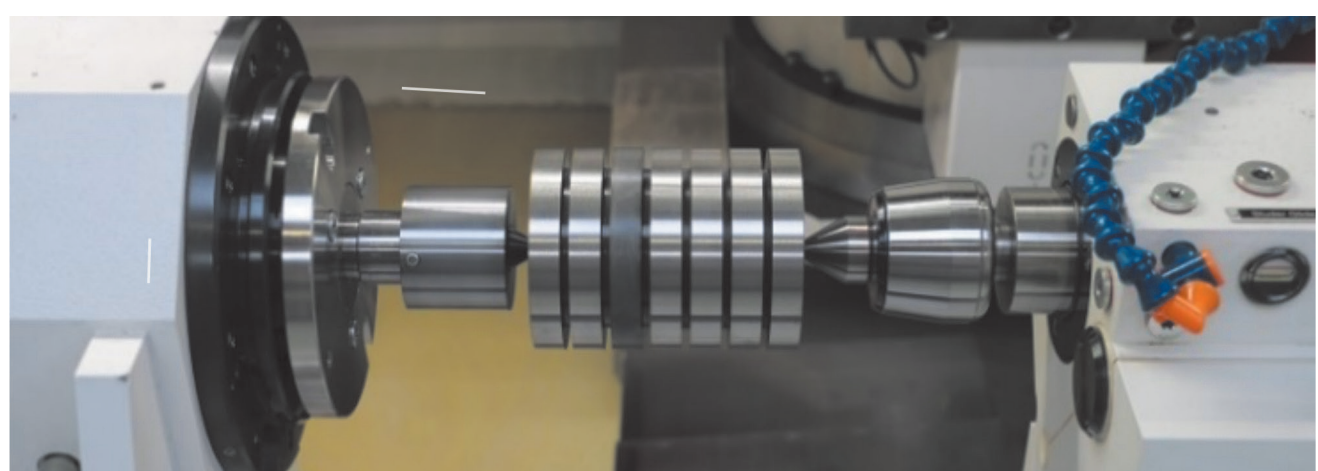


The specific material removal rate $Q_{w}^{\prime}$ generally correlates with the thermo-mechanical load acting on the component during the grinding process [4]. In order to generate different thermo-mechanical surface conditions on each individual workpiece segment, the specific material removal rate was varied from segment to segment by adjusting the radial feed velocity $\mathrm{v}_{\mathrm{fr}}$. An overview about the variation of the specific material removal rate is shown in Table 4 . Table 5 also lists the other process and dressing parameters.

Following an industrial standard procedure, spark-out was applied for two seconds subsequent grinding. Before carrying out each test point, the grinding wheel was dressed in order to ensure identical initial conditions and to avoid influences due to wear or clogging of the grinding wheel. Each test point was carried out three times for an evaluation of the repeatability.

After grinding, the resulting surface integrity was examined in detail. For this purpose, residual stress depth profiles were determined radiographically using $\mathrm{Cr}-\mathrm{Ka}$ radiation along the $\{211\}$ diffraction lines of martensite. The measurements were performed in the chi mode of the $\sin ^{2} \psi$ method at $13 \psi$-angles ranging from $-45^{\circ}$ to $+45^{\circ}$. To determine depth profiles, the material was electrochemically ablated stepwise to a depth of about $200 \mu \mathrm{m}$. In addition, cross-sections were done and temper etching was performed. The Barkhausen noise was determined using the Rollscan 350 from Stresstech $\mathrm{GmbH}$. In accordance with a procedural instruction of the Forschungsvereinigung Antriebstechnik e.V. [20], a magnetization frequency $\mathrm{f}_{\mathrm{M}}$ of $125 \mathrm{~Hz}$ and a magnetization voltage $U_{M}$ of $4.5 \mathrm{~V}$ were used. The analyzing frequency $\mathrm{f}_{\mathrm{a}}$ was filtered with a bandpass in the range of $70 \mathrm{kHz}$ to $200 \mathrm{kHz}$. These settings result in an analyzing depth of approx. $50 \mu \mathrm{m}$.
Das bezogene Zeitspanvolumen $Q_{w}^{\prime}$ korreliert grundsätzlich mit der auf das Bauteil wirkenden thermo-mechanischen Belastung während dem Schleifprozess [4]. Um an den einzelnen Bauteilsegmenten unterschiedliche thermo-mechanische Randzonenbeeinflussungen zu generieren, wurde das bezogene Zeitspanvolumen über eine Anpassung der radialen Vorschubgeschwindigkeit $v_{\text {fr }}$ von Segment zu Segment variiert. Eine Übersicht über die Variation des bezogenen Zeitspanvolumens ist in Tabelle 4 dargestellt. In Tabelle 5 sind zudem die übrigen Prozess- und Abrichtparameter aufgelistet.

Im Anschluss der Schleifbearbeitung wurde in Anlehnung an eine industrieübliche Vorgehensweise zwei Sekunden lang ausgefunkt. Vor jedem Schleifversuch wurde die Schleifscheibe abgerichtet, um identische Ausgangsbedingungen zu schaffen und Einflüsse durch beispielsweise Verschleiß oder Zusetzungen an der Schleifscheibe zu vermeiden. Um eine Aussage über die Wiederholgenauigkeit treffen zu können, wurden alle Schleifversuche jeweils dreifach wiederholt.

Nach dem Schleifen wurden die generierten Randzonenzustände detailliert untersucht. Dazu wurden Eigenspannungstiefenverläufe röntgenografisch mittels $\mathrm{Cr}$-Ka-Strahlung entlang der \{211\}-Beugungslinien des Martensits bestimmt. Die Messungen wurden im Chi-Modus des $\sin ^{2} \psi$-Verfahrens in $13 \psi$-Winkeln im Bereich von $-45^{\circ}$ bis $+45^{\circ}$ durchgeführt. Zur Ermittlung von Tiefenverläufen wurde das Material schrittweise bis in eine Tiefe von ca. $200 \mu \mathrm{m}$ elektrochemisch abgetragen. Zudem wurden Schliffbilder angefertigt und eine Nitalätzung durchgeführt. Das Barkhausenrauschen wurde mit dem Rollscan 350 der Stresstech GmbH ermittelt. Dabei wurde in Anlehnung an eine Verfahrensanweisung der Forschungsvereinigung Antriebstechnik e.V. [20] eine Magnetisierungsfrequenz $\mathrm{f}_{\mathrm{M}}$ von $125 \mathrm{~Hz}$ und eine Magnetisierungsspannung $U_{M}$ von $4,5 \mathrm{~V}$ eingesetzt. Die Analysierfrequenz $\mathrm{f}_{\mathrm{a}}$ wurde mit einem Bandpass im Bereich von $70 \mathrm{kHz}$ bis $200 \mathrm{kHz}$ gefiltert. Mit diesen Einstellungen ergibt sich eine Analysiertiefe von ca. $50 \mu \mathrm{m}$.

\begin{tabular}{|c|c|c|c|c|c|c|c|c|c|c|c|}
\hline I & II & III & IV & V & VI & VII & VIII & IX & X & XI & XII \\
\hline 0,5 & 1 & 2 & 4 & 6 & 8 & 10 & 12 & 14 & 16 & 20 & 24 \\
\hline
\end{tabular}

Table 4. Variation of the specific material removal rate $Q_{w}^{\prime}$

Tabelle 4. Variation des bezogenen Zeitspanvolumens $\mathrm{Q}_{\mathrm{w}}$

\begin{tabular}{|c|c|c|c|}
\hline \multicolumn{4}{|c|}{ Prozessparameter } \\
\hline Schnittgeschwindigkeit & $\mathrm{v}_{\mathrm{c}}$ & $\mathrm{m} / \mathrm{s}$ & 35 \\
\hline Geschwindigkeitsverhältnis & $\mathrm{q}$ & - & 90 \\
\hline Radiale Gesamtzustellung & $\mathrm{Z}$ & $\mu \mathrm{m}$ & 175 \\
\hline KSS-Versorgung & $\mathrm{Q}_{\mathrm{KSS}}$ & $\mathrm{l} / \mathrm{min}$ & 40 \\
\hline \multicolumn{4}{|c|}{ Abrichtparameter } \\
\hline Radiale Abrichtzustellung & $\mathrm{a}_{\mathrm{ed}}$ & $\mu \mathrm{m}$ & $2 \cdot 20$ \\
\hline Abrichtüberdeckungsgrad & $\mathrm{U}_{\mathrm{d}}$ & - & 4 \\
\hline Geschwindigkeitsverhältnis & $\mathrm{q}_{\mathrm{d}}$ & - & 0,8 \\
\hline
\end{tabular}

Table 5. Process and dressing parameters

Tabelle 5. Prozess- und Abrichtparameter 


\section{Characterization of the thermo-mechanical influence on the surface integrity}

First, the thermo-mechanical load acting on the workpiece surface during grinding was evaluated. For this purpose, a mutual mean value of the acting tangential grinding force $\mathrm{F}_{\mathrm{t}}$ and the effective power $\mathrm{P}$ was determined for all material states and all specimens as a function of the specific material removal rate $Q_{w^{\prime}}$. The results are shown in Figure 2, indicating the single standard deviation $\sigma$ (scatter bars).

It is clear that, irrespective of the material condition, similar process forces and effective powers occur for the same specific material removal rates $Q_{\mathrm{w}}{ }^{\prime}$. For this reason, a comparable thermo-mechanical influence on the surface integrity by the grinding process is assumed. Possible differences in the Barkhausen noise signals at different material states can therefore not be ascribed to a varying grinding behavior and are thus directly caused by the material state.

The characterization of the surface integrity resulting from the grinding process was mainly carried out on the basis of residual stress depth profiles and metallographic cross-sections. Figure 3 shows characteristic residual stress depth profiles on the BGH_1.0_0.6 material state [21]. The simple standard deviation $\sigma$ is basically low and ranges from 7.6 MPa to $29.2 \mathrm{MPa}$.

Up to a specific material removal rate $\mathrm{Q}_{\mathrm{w}}$ of $2 \mathrm{~mm}^{3} / \mathrm{mm} \times \mathrm{s}$, no significant influence is observed due to the increasing thermo-mechanical load during grinding. Higher material removal rates, however, lead to a shift of the resulting residual stresses towards the tensile range. Tensile residual stresses occur for the first time applying a specific material removal rate of $\mathrm{Q}_{\mathrm{w}}=6 \mathrm{~mm}^{3} / \mathrm{mm} \times \mathrm{s}$. The maximum value determined is $150 \mathrm{MPa}$ and occurs at a depth $\mathrm{t}$ of $10 \mu \mathrm{m}$. Further increasing material removal rates lead to high-

\section{Charakterisierung der thermo- mechanischen Randzonenbeeinflussung}

Zunächst wurde die während der Schleifbearbeitung wirkende thermo-mechanische Belastung der Werkstückrandzone evaluiert. Dazu wurde für alle Werkstoffzustände und alle Proben ein gemeinsamer Mittelwert der wirkenden tangentialen Schleifkraft $\mathrm{F}_{\mathrm{t}}$ bzw. der Wirkleistung P in Abhängigkeit vom bezogenen Zeitspanvolumen $Q_{w}$ bestimmt. Die Ergebnisse sind in Bild 2 unter Angabe der einfachen Standardabweichung $\sigma$ dargestellt. Es handelt sich dabei um Streubalken.

Es wird deutlich, dass unabhängig vom Werkstoffzustand ähnliche Prozesskräfte bzw. Wirkleistungen bei gleichen bezogenen Zeitspanvolumina $\mathrm{Q}_{\mathrm{w}}^{\mathrm{w}}$ auftreten. Aus diesem Grund wird von einer vergleichbaren thermo-mechanischen Randzonenbeeinflussung durch den Schleifprozess ausgegangen. Mögliche Unterschiede in den Signalen des Barkhausenrauschens an verschiedenen Werkstoffzuständen lassen sich demnach nicht auf ein variierendes Schleifverhalten zurückführen und werden somit direkt durch den Werkstoffzustand bedingt.

Die Charakterisierung des aus der Schleifbearbeitung resultierenden Randzonenzustands wurde vorwiegend anhand von Eigenspannungstiefenverläufen und metallografischen Schliffbildern durchgeführt. In Bild 3 sind charakteristische Eigenspannungstiefenverläufe am Werkstoffzustand BGH_1,0_0,6 dargestellt [21]. Die einfache Standardabweichung $\sigma$ ist grundsätzlich gering und befindet sich in einem Bereich von 7,6 MPa bis 29,2 MPa.

Bis zu einem bezogenen Zeitspanvolumen $\mathrm{Q}_{\mathrm{w}}$ von $2 \mathrm{~mm}^{3} / \mathrm{mm} \times \mathrm{s}$ ist zunächst kein signifikanter Einfluss durch die zunehmende thermo-mechanische Belastung während des Schleifprozesses festzustellen. Höhere Zeitspanvolumina führen dagegen zu einer Verschiebung der resultierenden Eigenspannungen in Richtung des Zugbereichs. $\mathrm{Ab}$ einem bezogenen Zeitspanvolumen von $\mathrm{Q}_{\mathrm{w}}^{\prime}=6 \mathrm{~mm}^{3} / \mathrm{mm} \times \mathrm{s}$ treten erstmals Zugeigenspannungen auf. Der ermittelte Maximalwert liegt bei $150 \mathrm{MPa}$ und tritt in einer Tiefe $\mathrm{t}$ von $10 \mu \mathrm{m}$ auf.

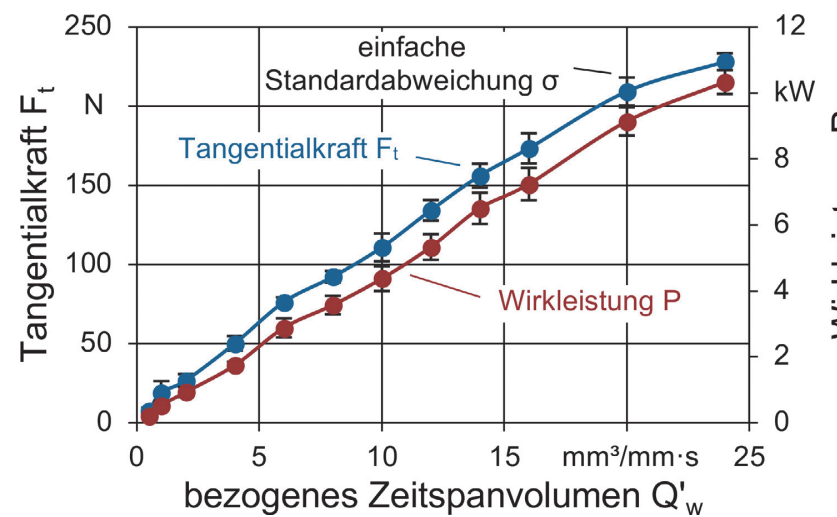

Fig. 2. Mutual mean values of the acting tangential force $F_{t}$ and the effective power $\mathrm{P}$ of all material states as a function of the specific material removal rate $Q_{w}^{\prime}$

Bild 2. Gemeinsame Mittelwerte der wirkenden Tangentialkraft $F_{t}$ bzw. der Wirkleistung $P$ aller Werkstoffzustände in Abhängigkeit des bezogenen Zeitspanvolumens $\mathrm{Q}_{\mathrm{w}}^{\prime}$

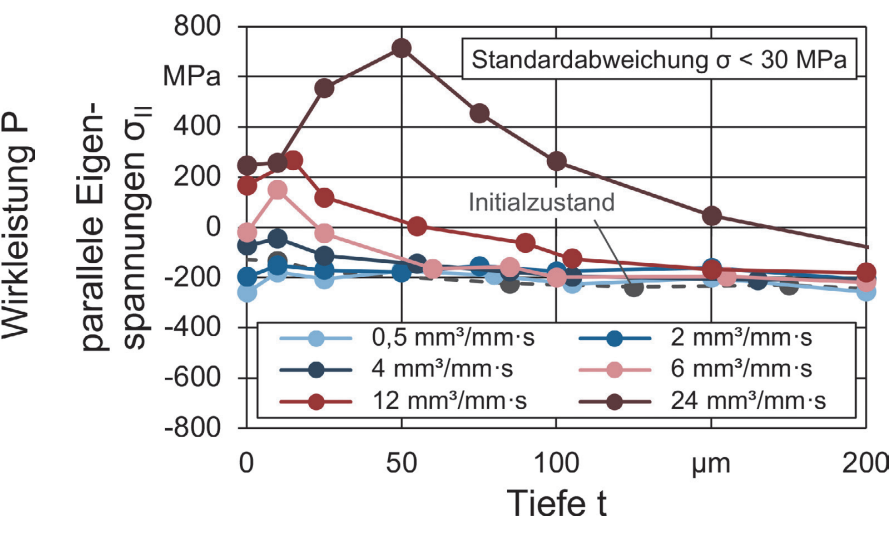

Fig. 3. Characteristic residual stress depth profiles at material condition BGH_1.0_0.6 [21]

Bild 3. Charakteristische Eigenspannungstiefenverläufe am Werkstoffzustand BGH_1,0_0,6 [21] 
er residual tensile stresses up to values of $750 \mathrm{MPa}$ at a specific material removal rate of $24 \mathrm{~mm}^{3} / \mathrm{mm} \times \mathrm{s}$. In addition, the occurring tensile stress maximum shifts to deeper material regions with increasing thermo-mechanical loads on the material surface. For a comparison between individual material states, Figure 4 shows the residual stress depth profiles of all material states after machining with the specific material removal rates $Q_{\mathrm{W}}=1 \mathrm{~mm}^{3}$ / $\mathrm{mm} \times \mathrm{s}$ and $24 \mathrm{~mm}^{3} / \mathrm{mm} \times \mathrm{s}$, respectively.

It is clear that the influence on the material condition after machining with a specific material removal rate $Q_{W}$ of $1 \mathrm{~mm}^{3} / \mathrm{mm} \times \mathrm{s}$ is low in all cases. Instead, an influence of the heat treatment to achieve different target values can be seen in the form of diverging residual stress states, especially in material depth. This observation and the related influence on the Barkhausen noise will be discussed in more detail in Chapter 4. After machining with a material removal rate of $24 \mathrm{~mm}^{3} / \mathrm{mm} \times \mathrm{s}$, on the other hand, a clear influence by the grinding process is visible. In principle, the values determined are at a comparable level, although higher fluctuations occur in the residual stress state as for machining with a material removal rate of $1 \mathrm{~mm}^{3} / \mathrm{mm} \times \mathrm{s}$, irrespective of the material state. These fluctuations indicate minor differences in the expression of the surface integrity at high specific material removal rates. In addition to the residual stress depth profiles, metallographic micrographs were prepared. Figure 5 shows cross-sections of the surface near area after grinding with the specific material removal rates 1,12 and $24 \mathrm{~mm}^{3} / \mathrm{mm} \times \mathrm{s}$ based on the material state BGH_1.0_0.6 [21].

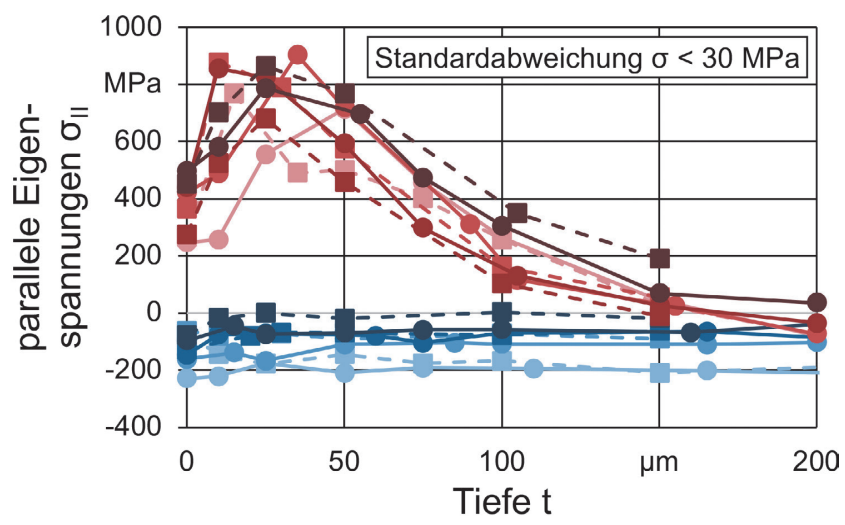

Weiter zunehmende Zeitspanvolumina führen zu höheren Zugeigenspannungen bis hin zu Werten von $750 \mathrm{MPa}$ bei einem bezogenen Zeitspanvolumen von $24 \mathrm{~mm}^{3} / \mathrm{mm} \times \mathrm{s}$. Zudem verschiebt sich das auftretende Zugspannungsmaximum mit zunehmender thermo-mechanischen Einwirkung auf die Randzone in tiefere Materialbereiche. Für einen Vergleich der einzelnen Werkstoffzustände sind in Bild 4 ihre Eigenspannungstiefenverläufe nach einer Bearbeitung mit den bezogenen Zeitspanvolumina $\mathrm{Q}_{\mathrm{w}}=1 \mathrm{~mm}^{3} / \mathrm{mm} \times \mathrm{s}$ bzw. $24 \mathrm{~mm}^{3} / \mathrm{mm} \times \mathrm{s}$ zu sehen.

Es wird deutlich, dass die Randzonenbeeinflussung nach einer Bearbeitung mit einem bezogenen Zeitspanvolumen $\mathrm{Q}_{\mathrm{w}}$ von $1 \mathrm{~mm}^{3} / \mathrm{mm} \times \mathrm{s}$ in allen Fällen gering ist. Stattdessen kann insbesondere in die Tiefe hinein ein Einfluss der Wärmebehandlung zur Erreichung unterschiedlicher Zielwerte in der Ausprägung der Eigenspannungszustände erkannt werden. Auf diese Beobachtung und den damit zusammenhängenden Einfluss auf das Barkhausenrauschen wird in Kapitel 4 detaillierter eingegangen. Nach einer Bearbeitung mit einem Zeitspanvolumen von $24 \mathrm{~mm}^{3} / \mathrm{mm} \times \mathrm{s}$ ist dagegen eine deutliche Beeinflussung durch die Schleifbearbeitung erkennbar. Grundsätzlich befinden sich die ermittelten Werte auf einem vergleichbaren Niveau, wobei im Eigenspannungszustand unabhängig vom Werkstoffzustand höhere Schwankungen als zuvor bei der Bearbeitung mit einem Zeitspanvolumen von $1 \mathrm{~mm}^{3} / \mathrm{mm} \times \mathrm{s}$ auftreten. Diese Schwankungen deuten auf geringfügige Unterschiede in der Ausprägung des Randzonenzustands bei hohen bezogenen Zeitspanvolumina hin. Zusätzlich zu den Eigenspannungstiefenverläufen wurden metallografische Schliffbilder angefertigt. In Bild 5 sind exemplarisch die Schliffbilder der Randzone nach der Schleifbearbeitung mit den bezogenen Zeitspanvolumina 1,12 und $24 \mathrm{~mm}^{3} / \mathrm{mm} \times \mathrm{s}$ anhand des Werkstoffzustands BGH_1,0_0,6 dargestellt [21].

\begin{tabular}{|c|c|}
\hline$\longrightarrow$ BGH_1,0_0,6 (1) & - - - DEW_1,0_0,6 (1) \\
\hline$\longrightarrow$ BGH_1,0_0,8 (1) & $--\div$ - DEW_1,0_0,8 (1) \\
\hline$\longrightarrow$ BGH_2,2_0,6 (1) & $-\rightarrow-$ DEW_2,2_0,6 (1) \\
\hline$\longrightarrow$ BGH_2,2_0,8 (1) & $-\rightarrow-D E W \_2,2 \_0,8(1)$ \\
\hline$\longrightarrow$ BGH_1,0_0,6 (24) & $--1-$ DEW_1,0_0,6 (24) \\
\hline$\longrightarrow$ BGH_1,0_0,8 (24) & - - - DEW_1,0_0,8 (24) \\
\hline$\longrightarrow$ BGH_2,2_0,6 (24) & $-\rightarrow-$ DEW_2,2_0,6 (24) \\
\hline$\longrightarrow$ BGH_2,2_0,8 (24) & $--1-$ DEW_2,2_0,8(24) \\
\hline
\end{tabular}

Fig. 4. Residual stress depth profiles of all material states for the specific material removal rates $Q_{w}^{\prime}=1$ and $24 \mathrm{~mm}^{3} / \mathrm{mm} \times \mathrm{s}$, respectively

Bild 4. Eigenspannungstiefenverläufe aller Werkstoffzustände für die bezogenen Zeitspanvolumina $Q_{w}^{\prime}=1 \mathrm{bzw} .24 \mathrm{~mm}^{3} / \mathrm{mm} \times \mathrm{s}$

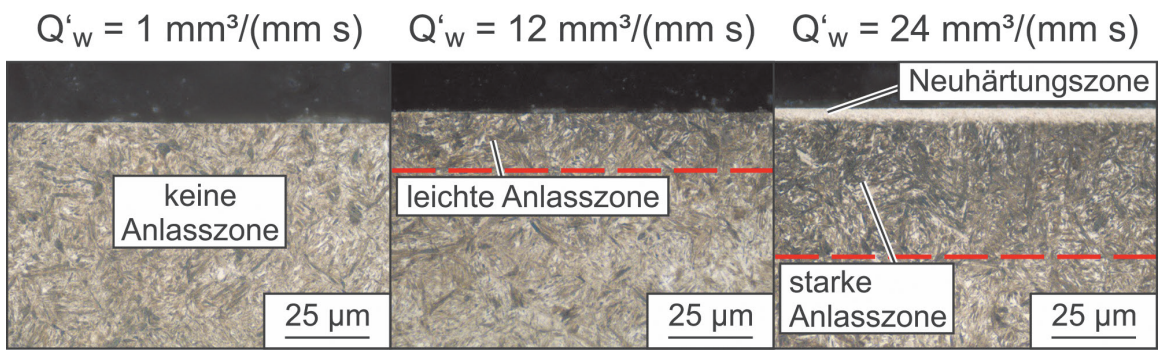

Fig. 5. Metallographic cross-sections of the surface near area after grinding with a specific material removal rate $Q_{w}^{\prime}$ of 1,12 and $24 \mathrm{~mm}^{3} /$ $\mathrm{mm} \times \mathrm{s}$ (material state BGH_1.0_0.6) [21]

Bild 5. Metallografische Schliffbilder der Randzone nach der Schleifbearbeitung mit einem bezogenen Zeitspanvolumen $\mathrm{Q}_{\mathrm{w}}$ von 1,12 und $24 \mathrm{~mm}^{3} / \mathrm{mm} \times \mathrm{s}$ (Werkstoffzustand BGH_1,0_0,6) [21] 
Grinding with a specific material removal rate $Q_{w}^{\prime}$ of $1 \mathrm{~mm}^{3} / \mathrm{mm} \times \mathrm{s}$ did not significantly influence the microstructure. An increase of the material removal rate to $12 \mathrm{~mm}^{3} / \mathrm{mm} \times \mathrm{s}$, on the other hand, leads to the occurrence of light tempering zones, while a specific material removal rate of $24 \mathrm{~mm}^{3} / \mathrm{mm} \times \mathrm{s}$ results in the formation of a thin rehardening zone with an underlying strong tempering zone. For the remaining material conditions, predominantly similar results are observed. Slight differences result from the fact that light tempering zones partly already occur at a specific material removal rate of $10 \mathrm{~mm}^{3} / \mathrm{mm} \times \mathrm{s}$ (e.g. BGH_1.0_0.8). On other material conditions, however, no rehardening zones could be detected even at a material removal rate of $24 \mathrm{~mm}^{3} / \mathrm{mm} \times$ s (e. g. BGH_2.2_0.6). The results of temper etching confirmed these observations. In summary, a continuous increase of the thermo-mechanical influence on the surface near area of the workpiece with increasing specific material removal rates $Q_{w}^{\prime}$ is shown.

\section{Evaluation and discussion of material- specific influences on the Barkhausen noise}

In order to investigate the influence of the material state on the Barkhausen noise as a function of the surface integrity, it is first necessary to classify characteristic workpiece conditions that are comparable under the individual material state. In industrial practice, the evaluation of ground components is usually carried out on the basis of temper etching classes A (damage-free reference), B (light tempering zone), D (strong tempering zone) and $\mathrm{E}$ (rehardening zone) defined in ISO 14104 [22]. This approach is adopted for the investigations presented.

The investigations in Chapter 3 have shown that a specific material removal rate $Q_{W}^{\prime}$ of $1 \mathrm{~mm}^{3} / \mathrm{mm} \times s$ does not have any significant negative influence on the surface integrity in terms of thermo-mechanical damage. For this reason, the surface integrity resulting from the grinding process with a specific material removal rate $Q_{w}{ }_{w}$ of $1 \mathrm{~mm}^{3} / \mathrm{mm} \times \mathrm{s}$ is defined as damage-free reference analogous to temper etching class A. The development of the RMS-value as a function of the specific material removal rate is used for the determination of a surface integrity corresponding to temper etching class B.

Figure 6 shows the development of the RMS-value for the material condition BGH_1.0_0.6 with indication of the simple standard deviation $\sigma$ from five measurements each on all three identically ground workpiece segments (15 individual measurements). It can be seen that the RMS-value reaches a maximum value with the occurrence of light tempering zones at a specific material removal rate of $12 \mathrm{~mm}^{3} / \mathrm{mm} \times \mathrm{s}$ (cf. Chapter 3). An increasing thermo-mechanically influenced surface area beyond this leads to a signal decrease. The RMS-signals at the other material states behave analogously. Based on this observation, the RMS-value of temper
Durch das Schleifen mit einem bezogenen Zeitspanvolumen $\mathrm{Q}_{\mathrm{w}}$ von $1 \mathrm{~mm}^{3} / \mathrm{mm} \times \mathrm{s}$ ist keine signifikante Beeinflussung des Gefügezustands erfolgt. Eine Erhöhung des Zeitspanvolumens auf $12 \mathrm{~mm}^{3} / \mathrm{mm} \times \mathrm{s}$ führt dagegen zum Auftreten leichter Anlasszonen, während ein bezogenes Zeitspanvolumen von $24 \mathrm{~mm}^{3} / \mathrm{mm} \times \mathrm{s}$ in der Ausprägung einer dünnen Neuhärtungszone mit darunter liegender starker Anlasszone resultiert. Bei den übrigen Werkstoffzuständen sind überwiegend ähnliche Ergebnisse zu beobachten. Geringe Unterschiede ergeben sich dadurch, dass leichte Anlasszonen zum Teil bereits ab einem bezogenen Zeitspanvolumen von $10 \mathrm{~mm}^{3} / \mathrm{mm} \times \mathrm{s}$ (bspw. BGH_1,0_0,8) auftreten. An anderen Werkstoffzuständen konnten dagegen auch bei einem Zeitspanvolumen von $24 \mathrm{~mm}^{3} / \mathrm{mm} \times$ s keine Neuhärtungszonen nachgewiesen werden (z. B. BGH_2,2_0,6). Die Ergebnisse der Nitalätzung haben diese Beobachtungen bestätigt. Zusammenfassend zeigt sich eine kontinuierliche Zunahme des thermo-mechanischen Einflusses auf den Randzonenzustand mit zunehmenden bezogenen Zeitspanvolumina $\mathrm{Q}_{\mathrm{w}}$.

\section{Auswertung und Diskussion der werkstoff- spezifischen Einflüsse auf das Barkhausen- rauschen}

Um die Beeinflussung des Barkhausenrauschens durch den Werkstoffzustand in Abhängigkeit des Randzonenzustands zu untersuchen, ist zunächst die Zuweisung charakteristischer, unter den einzelnen Werkstoffzuständen vergleichbarer Randzonenzustände erforderlich. In der industriellen Praxis erfolgt die Bewertung geschliffener Bauteile in der Regel anhand der in der ISO 14104 [22] definierten Nitalätzklassen A (schädigungsfreie Referenz), B (leichte Anlasszone), D (starke Anlasszone) und E (Neuhärtungszone). Diese Vorgehensweise wird für die vorgestellten Untersuchungen übernommen.

Die Untersuchungen in Kapitel 3 haben gezeigt, dass durch ein bezogenes Zeitspanvolumen $\mathrm{Q}_{\mathrm{w}}$ von $1 \mathrm{~mm}^{3} / \mathrm{mm} \times \mathrm{s}$ keine signifikante negative Beeinflussung der Randzone im Sinne thermo-mechanischer Randzonenschädigungen erfolgt. Aus diesem Grund wird der Randzonenzustand, der sich aus dem Schleifprozess mit einem bezogenen Zeitspanvolumen $Q_{W}{ }_{w}$ von $1 \mathrm{~mm}^{3} / \mathrm{mm} \times \mathrm{s}$ ergibt, als schädigungsfreier Referenzzustand analog zur Nitalätzklasse A definiert. Für die Zuweisung einer Randzonenbeeinflussung entsprechend der Nitalätzklasse B wird die Entwicklung des RMS-Werts in Abhängigkeit vom bezogenen Zeitspanvolumen herangezogen.

In Bild 6 ist exemplarisch der Verlauf des RMS-Werts für den Werkstoffzustand BGH_1,0_0,6 unter Angabe der einfachen Standardabweichung $\sigma$ aus jeweils fünf Messungen an allen drei identisch geschliffenen Werkstücksegmenten (15 Einzelmessungen) dargestellt. Es ist erkennbar, dass der RMS-Wert mit dem Auftreten leichter Anlasszonen bei einem bezogenen Zeitspanvolumen von $12 \mathrm{~mm}^{3} / \mathrm{mm} \times \mathrm{s}$ (vgl. Kapitel 3) einen maximalen Wert annimmt. Eine darüber hinaus zunehmende thermo-mechanische Randzonenbeeinflussung führt zu einer Signalabnahme. Die RMS-Signale an den übrigen Werkstoffzuständen verhalten sich 


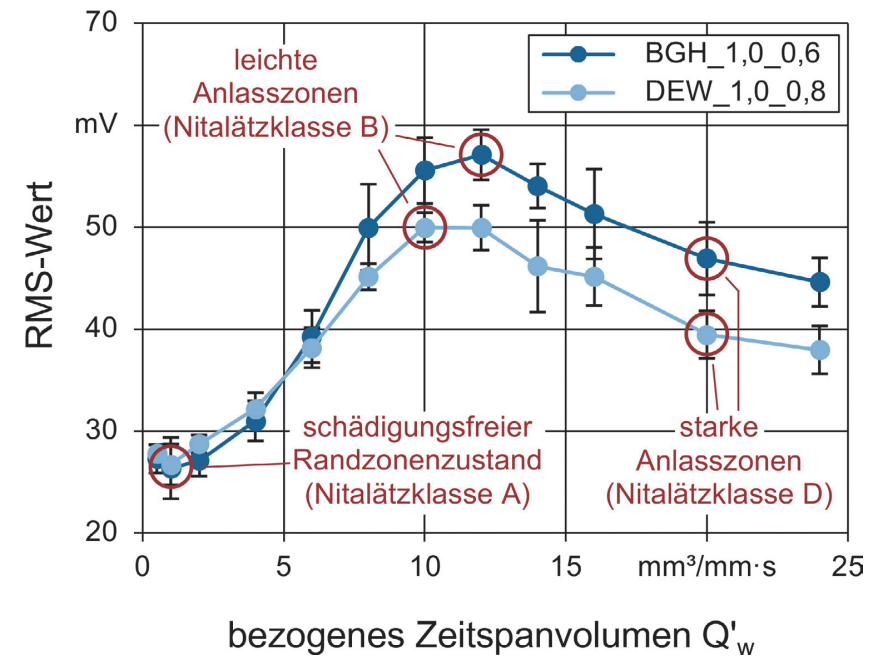

etching class $B$ is determined by the determined maximum value in the following.

In addition, a strong tempering zone after grinding with a specific material removal rate of $\mathrm{Q}_{\mathrm{w}}^{\prime}=20 \mathrm{~mm}^{3} / \mathrm{mm} \times \mathrm{s}$ was observed on all material states. The corresponding RMS-value is therefore used for temper etching class D. Since no rehardening zones occurred on some material states, their influence on the Barkhausen noise is not evaluated in detail within the scope of these investigations. However, it is known from the literature that an increasing formation of rehardening zones is associated with a further decrease of the RMS-value down to the base level of the damage-free reference state [23]. Table 6 provides an overview of the RMS-values determined using this approach as a function of the surface integrity and material state. The arithmetic mean value of all three specimens of a material state is shown. The measured values are shown graphically in Figure 7. Irrespective of the surface integrity, only a slight influence of the material batch on the RMS-value of the Barkhausen noise can be observed, with an average signal reduced by approx. $5.3 \%$ for the DEW batch.

\begin{tabular}{|c|c|c|c|}
\hline $\begin{array}{c}\text { Werkstoff- } \\
\text { zustand }\end{array}$ & $\begin{array}{c}\text { RMS-Wert } \\
\text { Nitalätzklasse } \\
\text { A [mV] }\end{array}$ & $\begin{array}{c}\text { RMS-Wert } \\
\text { Nitalätzklasse } \\
\text { B [mV] }\end{array}$ & $\begin{array}{c}\text { RMS-Wert } \\
\text { Nitalätzklasse } \\
\text { D [mV] }\end{array}$ \\
\hline BGH_1,0_0,6 & 26,35 & 57,09 & 46,90 \\
\hline BGH_1,0_0,8 & 30,25 & 51,72 & 40,66 \\
\hline BGH_2,2_0,6 & 35,53 & 62,60 & 57,57 \\
\hline BGH_2,2_0,8 & 43,01 & 73,23 & 55,92 \\
\hline DEW_1,0_0,6 & 25,99 & 52,79 & 45,95 \\
\hline DEW_1,0_0,8 & 26,71 & 49,96 & 39,44 \\
\hline DEW_2,2_0,6 & 34,46 & 59,50 & 54,92 \\
\hline DEW_2,2_0,8 & 39,73 & 63,03 & 55,20 \\
\hline
\end{tabular}

Fig. 6. Development of the RMS value as a function of the specific material removal rate $\mathrm{Q}_{\mathrm{w}}^{\prime}$ (material condition BGH_1.0_0.6)

Bild 6. Entwicklung des RMS-Werts in Abhängigkeit des bezogenen Zeitspanvolumens ${ }^{\prime}{ }_{w}$ (Werkstoffzustand BGH_1,0_0,6)

analog dazu. Auf Grundlage dieser Beobachtung wird der RMSWert der Nitalätzklasse B im Folgenden durch den ermittelten Maximalwert bestimmt.

Darüber hinaus konnte an allen Werkstoffzuständen eine starke Anlasszone nach einer Schleifbearbeitung mit einem bezogenen Zeitspanvolumen von $\mathrm{Q}_{\mathrm{w}}=20 \mathrm{~mm}^{3} / \mathrm{mm} \times$ s festgestellt werden. Der zugehörige RMS-Wert wird daher für die Nitalätzklasse D herangezogen. Da an einigen Werkstoffzuständen keine Neuhärtungszonen aufgetreten sind, wird deren Einfluss auf das Barkhausenrauschen im Rahmen dieser Untersuchungen nicht im Detail evaluiert. Aus der Literatur ist jedoch bekannt, dass eine zunehmende Ausbildung von Neuhärtungszonen mit einer weiteren Abnahme des RMS-Werts bis auf das Grundniveau des schädigungsfreien Referenzzustands verbunden ist [23]. In Tabelle 6 ist eine Übersicht über die mit diesem Vorgehen ermittelten RMS-Werte in Abhängigkeit vom Rand- und Werkstoffzustand gegeben. Dargestellt ist der arithmetische Mittelwert aller drei Proben eines Werkstoffzustands. Die Messwerte sind in Bild 7 grafisch aufgearbeitet. Unabhängig vom Randzonenzustand ist lediglich ein geringer Einfluss der Werkstoffcharge auf den RMS-Wert des Barkhausenrauschens festzustellen, wobei sich für die Charge DEW im Mittel ein um ca. 5,3\% reduziertes Signal ergibt.

Tabelle 6. Development of the RMS-value as a function of the material
condition and surface integrity

Tabelle 6. Entwicklung des RMS-Werts in Abhängigkeit des Werkstoff- und Randzonenzustands 
Fig. 7. RMS-value (arithmetic mean) of Barkhausen noise for temper etching classes $A, B$ and $D$ as a function of material condition

Bild 7. RMS-Wert (arithmetischer Mittelwert) des Barkhausenrauschens für die Nitalätzklassen A, B und D in Abhängigkeit des Werkstoffzustands

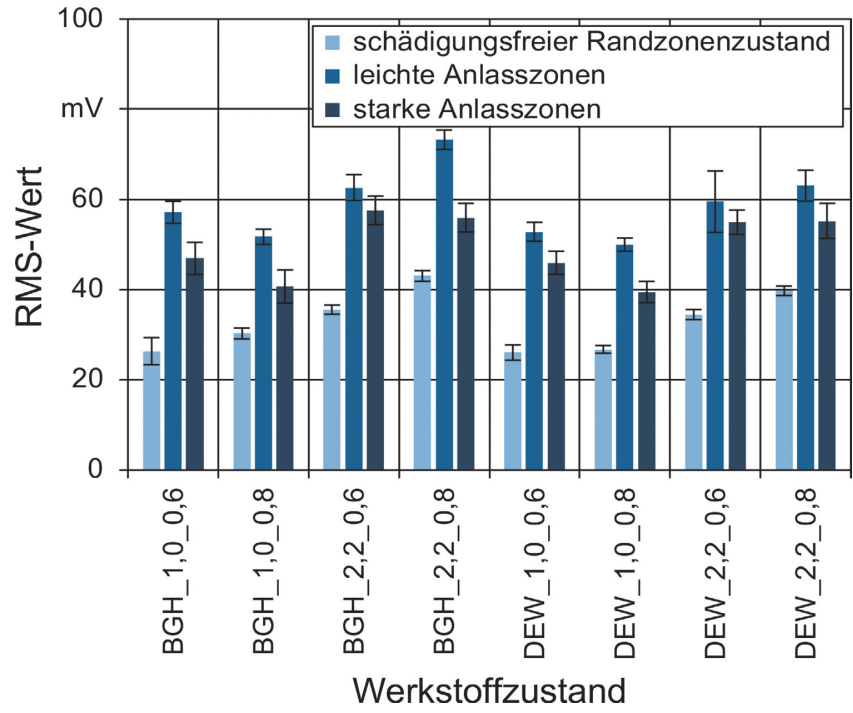

Liegt ein schädigungsfreier Randzonenzustand (Nitalätzklasse A) vor, ist sowohl mit zunehmendem Randkohlenstoffgehalt $c_{R}$ als auch mit zunehmender Einhärtetiefe EHT eine Zunahme des RMS-Werts zu erkennen. Die mittlere Zunahme durch die Erhöhung des Randkohlenstoffgehalts von $0,6 \mathrm{~m} \%$ auf $0,8 \mathrm{~m} \%$ beträgt ca. 13,5\%, während eine Erhöhung der Einhärtetiefe von 1,0 mm auf 2,2 mm eine Signalsteigerung um etwa 39,6 \% zur Folge hat.

Ähnlich wie bei dem schädigungsfreien Randzonenzustand führt eine höhere Einhärtetiefe auch beim Auftreten leichter Anlasszonen (Nitalätzklasse B) durchweg zu einem höheren Signal des RMS-Werts. Im Mittel nimmt der Wert um etwa 22,5 \% zu. In Abhängigkeit vom Randkohlenstoffgehalt ist dagegen ein widersprüchliches Verhalten erkennbar. In Kombination mit einer Einhärtetiefe von 1,0 mm ist eine Erhöhung des Randkohlenstoffgehalts von $0,6 \mathrm{~m} \%$ auf $0,8 \mathrm{~m} \%$ mit einer Abnahme des RMS-Signals (Veränderung um etwa $-7,4 \%$ ) verbunden, während dieselbe Erhöhung des Randkohlenstoffgehalts in Kombination mit einer Einhärtetiefe von 2,2 mm zu einer Signalsteigerung des RMSWerts von durchschnittlich ca. 5,9 \% führt.

Auch im Falle starker Anlasszonen (Nitalätzklasse D) ist zunächst eine Signalerhöhung mit höherer Einhärtetiefe zu sehen. Die Erhöhung des RMS-Signals beträgt im Durchschnitt ca. $29,9 \%$. Erneut fallen jedoch deutliche Unterschiede in Abhängigkeit von der Einhärtetiefe auf. So nimmt der RMS-Wert bei geringer Einhärtetiefe $(1,0 \mathrm{~mm})$ mit zunehmendem Randkohlenstoffgehalt im Mittel um ca. 13,7 \% ab, während die Abnahme bei einer Einhärtetiefe von 2,2 mm durchschnittlich lediglich etwa 1,2\% beträgt.

Es wird deutlich, dass es in Abhängigkeit vom Werkstoffzustand zu einem teils stark variierenden Signalverhalten des RMS-Werts kommt. Unterschiede beim Vorliegen des schädigungsfreien Randzonenzustands lassen sich vorwiegend mit Effekten aus der Wärmebehandlung begründen. So führt eine variierende Prozessführung zur Erreichung verschiedener Zielwerte während der Wärmebehandlung beispielsweise zu Unterschieden im Eigenspannungszustand, der das Barkhausenrauschen 
depth and a higher surface carbon content lead to low compressive residual stresses in the near-surface edge zone region and thus, as expected, to a higher RMS-signal.

In addition, different surface carbon contents or hardening depths lead to slight variations in the microstructural composition of the surface near area, which means an influence on the Barkhausen noise is likely $[10,11]$. However, the observations described suggest that this influence on the Barkhausen noise is to be subordinated in contrast to the influence of the residual stress state.

Once thermo-mechanically induced surface damages occur, the relationships are more complex. It was shown in Chapter 3 that grinding leads to a mainly uniform influence on the surface integrity, irrespective of the material state. If tempering zones occur, there is probably a complex superposition due to effects from the heat treatment (initial surface integrity) and the influence due to grinding. There is evidence that carbide precipitation, for example, leads to interactions with the RMS-value of the Barkhausen noise [9]. Tempering zones are usually formed by reaching a certain threshold temperature, above which carbon diffuses out of the case-hardened, martensitic matrix, leading to finely distributed precipitations [24]. It is conceivable that a higher content of carbon in the workpiece surface area leads to an earlier start and increased precipitation of carbides at constant thermo-mechanical loads on the workpiece, and therefore leads to a decrease in the RMS-value. The reason for the lower signal decrease at a hardening depth of $2.2 \mathrm{~mm}$ in combination with strong tempering zones or increasing RMS-values in the presence of light tempering zones, on the other hand, cannot be explained by the precipitation behavior.

Depending on the thermo-mechanical influence on the surface integrity during grinding with different specific material removal rates $Q_{w}{ }_{w}$, no significant or systematic influence on the retained austenite content could be found. The differences in the signal differences between different degrees of influence of one material

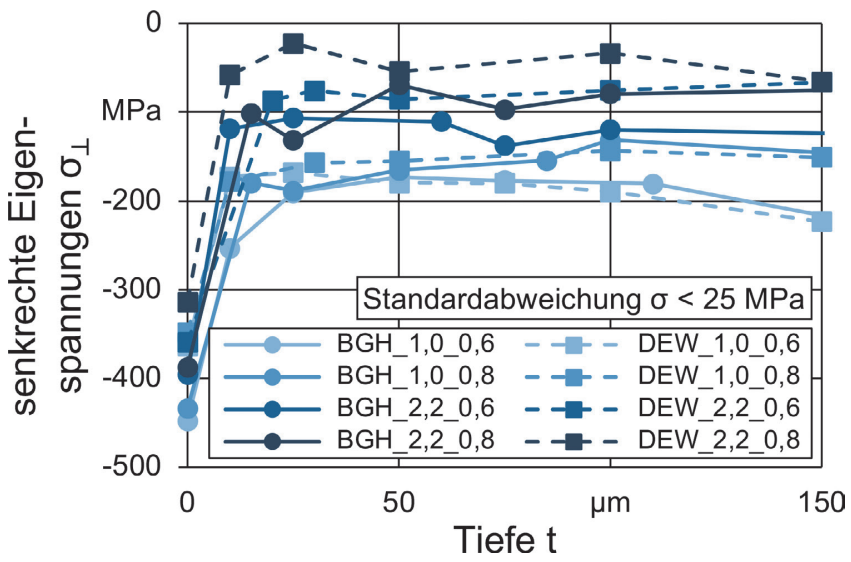

maßgeblich beeinflusst [5]. Dieser Effekt ist in Bild 8 dargestellt. Sowohl eine höhere Einhärtetiefe als auch ein höherer Randkohlenstoffgehalt führen zu geringen Druckeigenspannungen im oberflächennahen Randzonenbereich und damit erwartungsgemäß zu einem höheren RMS-Signal.

Darüber hinaus führen unterschiedliche Randkohlenstoffgehalte bzw. Einhärtetiefen zu geringfügigen Variationen in der Gefügezusammensetzung der Randzone, sodass eine Beeinflussung des Barkhausenrauschens wahrscheinlich ist $[10,11]$. Die beschriebenen Beobachtungen lassen jedoch vermuten, dass dieser Einfluss auf das Barkhausenrauschen der Beeinflussung durch den Eigenspannungszustand unterzuordnen ist.

Sobald thermo-mechanische Randzonenschädigungen auftreten, sind die Zusammenhänge vielschichtiger. In Kapitel 3 wurde gezeigt, dass die Schleifbearbeitung unabhängig vom Werkstoffzustand zu einer weitestgehend gleichmäßigen Randzonenbeeinflussung führt. Treten Anlasszonen auf, kommt es vermutlich zu einer komplexen Überlagerung durch Effekte aus der Wärmebehandlung (Randzonenausganszustand) und der Randzonenbeeinflussung durch die Schleifbearbeitung. So gibt es Hinweise darauf, dass beispielsweise Karbidausscheidungen zu Wechselwirkungen mit dem RMS-Wert des Barkhausenrauschens führen [9]. Anlasszonen entstehen üblicherweise durch das Erreichen einer bestimmten Grenztemperatur, ab welcher Kohlenstoff aus dem einsatzgehärteten, martensitischen Grundgefüge ausdiffundiert und zu fein verteilten Ausscheidungen führt [24]. Es ist denkbar, dass ein höherer Gehalt an Kohlenstoff im Randzonenbereich bei gleichbleibender thermo-mechanischer Belastung der Werkstückrandzone zu einer früher einsetzenden und erhöhten Ausscheidung von Karbiden führt, sodass eine Abnahme des RMSWerts resultiert. Die Ursache für die geringere Signalabnahme bei einer Einhärtetiefe von 2,2 mm in Kombination mit starken Anlasszonen bzw. zunehmenden RMS-Werten beim Vorliegen leichter Anlasszonen kann dagegen nicht durch das Ausscheidungsverhalten erklärt werden.

In Abhängigkeit von der thermo-mechanischen Randzonenbeeinflussung beim Schleifen mit unterschiedlichen bezogenen Zeitspanvolumina $Q_{W}^{c}$ konnte keine signifikante oder systematische Beeinflussung des Restaustenitgehalts festgestellt werden. Die Unterschiede in den Signaldifferenzen zwischen verschiede-
Fig. 8. Residual stress depth profiles of all material states after grinding $\left(\mathrm{Q}_{\mathrm{w}}^{\prime}=1 \mathrm{~mm}^{3} / \mathrm{mm} \times \mathrm{s}\right)$

Bild 8. Eigenspannungstiefenverläufe aller Werkstoffzustände nach der Schleifbearbeitung $\left(\mathrm{Q}_{\mathrm{w}}^{\prime}=1 \mathrm{~mm}^{3} / \mathrm{mm} \times \mathrm{s}\right)$ 
state to those of the other material states can thus not be explained on the basis of the existing retained austenite content.

It should be noted that the analyzing depth significantly influences the signal of the Barkhausen noise $[15,19]$. Thus, with increasing analyzing depth, an increasing influence of the deeper located tensile stress maxima in the case of, for example, strong tempering zones is to be expected, while the influence of the tempering zones originating from the surface decreases. Therefore, an overall less decreasing RMS-value can be expected with an increasing analyzing depth, if temepring zones are present. Since only minor differences were found for equal specific material removal rates $Q_{W}{ }_{W}$ during the characterization of the surface integrity (Chapter 3 ), no dominating effect of the analyzing depth on the differences discussed in this manuscript as a function of the material state is to be expected at this point.

\section{Summary and outlook}

In the investigations presented here, the influence of different material states in terms of hardening depth, surface carbon content and alloy composition on the RMS-value of the Barkhausen noise as a function of the surface integrity was evaluated in detail. It was shown that the material batch only slightly affects the Barkhausen noise. A higher hardness depth has consistently led to an increase in the signal of the RMS-value within the presented investigations.

In contrast, contrary observations were made for the surface carbon content depending on the surface integrity. If a damage-free surface is present, higher RMS-values are determined with an increasing surface carbon content. In combination with a hardening depth of $1.0 \mathrm{~mm}$, the occurrence of tempering zones has generally resulted in a decrease of the RMS-value with increasing surface carbon content. At a hardening depth of $2.2 \mathrm{~mm}$, in contrast, increasing RMS-values were determined in connection with light tempering zones, while the presence of strong tempering zones also resulted in a slightly decreasing RMS-value on average. In this context, it is assumed that previously unknown, non-trivial interactions of various influencing factors affect the Barkhausen noise. However, in order to describe these interactions in detail, further investigations are required. Of particular interest is the formation of tempering zones as a function of the surface carbon content and the resulting influence on the Barkhausen noise. It is known that the occurrence of tempering zones leads to a decrease in the RMS-value. However, the mechanisms responsible for this are still not known in detail. Nevertheless, it becomes clear that the signal level of the RMS-value is significantly influenced by the material condition and thus individual limiting criteria for the evaluation of the surface integrity have to be defined. nen Beeinflussungsgraden eines Werkstoffzustands zu denen der übrigen Werkstoffzustände können damit nicht anhand des vorliegenden Restaustenitgehalts erklärt werden.

$\mathrm{Zu}$ beachten ist, dass die Analysiertiefe das Signal des Barkhausenrauschens maßgeblich beeinflusst $[15,19]$. So ist mit einer zunehmenden Analysiertiefe ein zunehmender Einfluss der tiefer liegenden Zugspannungsmaxima im Falle von beispielsweise starken Anlasszonen zu erwarten, während der Einfluss der von der Oberfläche ausgehenden Anlasszonen abnimmt. Mit zunehmender Analysiertiefe ist somit von einem insgesamt weniger stark abfallenden RMS-Wert ab dem Auftreten von Anlasszonen im Allgemeinen zu rechnen. Da während der Charakterisierung der Randzonenzustände (Kapitel 3) lediglich geringfügige Differenzen für gleiche bezogene Zeitspanvolumina $Q_{w}$ festgestellt wurden, wird an dieser Stelle kein dominierender Effekt der Analysiertiefe auf die in diesem Manuskript diskutierten Unterschiede in Abhängigkeit des Werkstoffzustands erwartet.

\section{Zusammenfassung und Ausblick}

In den vorgestellten Untersuchungen wurde der Einfluss unterschiedlicher Werkstoffzustände hinsichtlich Einhärtetiefe, Randkohlenstoffgehalt und Legierungszusammensetzung auf den RMS-Wert des Barkhausenrauschens in Abhängigkeit des Randzonenzustands eingehend evaluiert. Es hat sich gezeigt, dass die Materialcharge das Barkhausenrauschen lediglich geringfügig beeinflusst. Eine höhere Einhärtetiefe hat in den vorgestellten Untersuchungen durchweg zu einer Signalsteigerung des RMS-Werts geführt.

Dementgegen sind in Abhängigkeit vom Randkohlenstoffgehalt je nach Randzonenzustand gegensätzliche Beobachtungen aufgetreten. Liegt ein schädigungsfreier Randzonenzustand vor, werden mit einem zunehmenden Randkohlenstoffgehalt höhere RMS-Werte ermittelt. In Kombination mit einer Einhärtetiefe von 1,0 $\mathrm{mm}$ hat das Auftreten von Anlasszonen allgemein zu einer Abnahme des RMS-Werts mit zunehmendem Randkohlenstoffgehalt geführt. Bei einer Einhärtetiefe von 2,2 mm wurden in Zusammenhang mit leichten Anlasszonen dagegen steigende RMS-Werte ermittelt, während das Vorliegen von starken Anlasszonen im Mittel ebenfalls in einem leicht abnehmenden RMS-Wert resultierte.Es wird davon ausgegangen, dass in diesem Zusammenhang bisher unbekannte, nicht triviale Wechselwirkungen verschiedener Einflussfaktoren auf das Barkhausenrauschen wirken. Um diese Wechselwirkungen detailliert zu beschreiben, sind jedoch weitere Untersuchungen erforderlich. Von besonderem Interesse ist dabei die Entstehung von Anlasszonen in Abhängigkeit vom Randkohlenstoffgehalt und die daraus resultierende Beeinflussung des Barkhausenrauschens. Es ist bekannt, dass das Auftreten von Anlasszonen zu einer Abnahme des RMS-Werts führt. Die dafür verantwortlichen Mechanismen sind jedoch nach wie vor nicht im Detail bekannt. Dennoch wird deutlich, dass die Signalhöhe des RMS-Werts maßgeblich durch den Werkstoffzustand beeinflusst wird und damit individuelle Grenzkriterien zur Bewertung des Randzonenzustands definiert werden müssen. 


\section{Acknowledgements}

This work was funded by the German Research Foundation DFG within the priority program SPP 2086. The authors thank the DFG for financial and technical support.

\section{References}

1. Denkena, B.; Tönshoff, H. K.: Spanen - Grundlagen. 3. Aufl., Springer-Verlag, Berlin, 2011. - ISBN: 978-3642197710

2. Klocke, F.: Fertigungsverfahren 2 - Zerspanung mit geometrisch unbestimmter Schneide. 6. Aufl., Springer-Verlag GmbH, Berlin, 2018. - ISBN: 978-3-66258092-9

3. Brinksmeier, E.: Prozeß- und Werkstückqualität in der Feinbearbeitung. Habilitationsschrift, Leibniz Universität Hannover, 1991

4. Karpuschewski, B.: Mikromagnetische Randzonenanalyse geschliffener einsatzgehärteter Bauteile. Dissertation, Leibniz Universität Hannover, 1995

5. Karpuschewski, B.; Bleicher, O.; Beutner, M.: Surface integrity inspection on gears using Barkhausen noise analysis. Procedia Eng. 19 (2011), pp. 162-171, DOI:10.1016/j.proeng.2011.11.096

6. Jiles, D. C.: Review of magnetic methods for nondestructive evaluation. NDT Intern. 21 (1988) 5, pp. 311-319

7. Chukwuchekwa, N.; Moses, A.; Anderson, P.: Barkhausen noise in grain-oriented $3 \%$ Si-Fe at 50 Hz. J. Electr. Eng. 61 (2010) 7, pp. 69-72

8. Donath, A.: Untersuchungen zum Einfluss ausgewählter Wärmebehandlungsverfahren auf den Barkhausen-Effekt und den reziproken magnetostriktiven Effekt bei Stählen. Dissertation, Technische Universität Dresden, 1990

9. Neslusan, M.; Cizek, J.; Kolarik, K.; Minarik, P.; Cillikova, M.; Melikhova, O.: Monitoring of grinding burn via Barkhausen noise emission in case-hardened steel in large-bearing production. J. Mat. Proc. Techn. 240 (2017), pp. 104-117, DOI:10.1016/j.jmatprotec.2016.09.015

10. Deng, Y.; Li, Z.; Chen, J.; Qi, X.: The effects of the structure characteristics on Magnetic Barkhausen noise in commercial steels. J. Magnetism Magnetic Mat. 451 (2018), pp. 276-282, DOI:10.1016/j.jmmm.2017.11.041

11. Santa-aho, S.; Vippola, M.; Sorsa, A.; Leiviskä, K.; Lindgren, M.; Lepistö, T.: Utilization of Barkhausen noise magnetizing sweeps for case-depth detection from hardened steel. NDT\&E Int. 52 (2012),pp. 95-102, DOI:10.1016/j.ndteint.2012.05.005

12. Cillikova, M.; Micieta, B.; Neslusan, M.; Blazek, D.: Nondestructive Magnetic Monitoring of Grinding Damage. Procedia Mat. Sc. 12 (2016), pp. 54-59, DOI:10.1016/j.mspro.2016.03.010

13. Suominen, L.; Woitijas, A.: A comparative study of Barkhausen noise and X-ray diffraction measurements from ground ferritic steel samples. Proc. of 4th European Conference on Residual Stresses. 04.-06.06.96, Cluny, France, Société Française de Métallurgie et de Matériaux, Cluny, France, 1996, pp. 243-250

14. Theiner, W. A.: Micromagnetic techniques. Structual and Residual Stress Analysis by Nondestructive Methods. V. Hauk (ed.), Elsevier Science B. V., Amsterdam, 1997, pp. 564-589, DOI:10.1016/B978-044482476-9/50019-0

15. Kypris, O.; Nlebedim, I. C.; Jiles, D. C.: Measuring stress variation with depth using Barkhausen signals. J. Magnetism Magnetic Mat. 407 (2016), pp.377-395, DOI:10.1016/j.jmmm.2016.01.072

\section{Danksagung}

Die Arbeit wurde von der Deutschen Forschungsgemeinschaft DFG im Rahmen des Schwerpunktprogramms SPP 2086 gefördert. Die Autoren danken der DFG für die finanzielle und technische Unterstützung.

16. Lasaosa, A.; Gurruchaga, K.; Arizti, F; Martinez-de-Guerenu, A.: Quantitative estimation of nonmonotonic residual stress depth-profiles using an extended KyprisJiles model of the magnetic Barkhausen noise spectrum. J. of Applied Physics 123 (2018) 3, pp. 1-11, DOI:10.1063/1.5002074

17. Mierczak, L. P.; Melikhov, Y.; Jiles, D. C.: Determining Residual Stress Depth Profiles Using the Magnetic Barkhausen Effect. IEEE Transactions on Magnetics 50 (2014) 10, pp. 1-5, DOI:10.1109/TMAG.2014.2329455

18. Vaidhianathasamy, M.: Important Factors Influencing the Magnetic Barkhausen Noise Profile. IEEE Transactions on Magnetics 52 (2016) 4, pp. 1-13, DOI:10.1109/ TMAG.2015.2502222

19. Tomkowski, R.; Jonsson, S.; Lundin, P.; Nerman, P.: Penetration depth investigation of Barkhausen noise signal for case-hardened components. Proc. Micromagnetic testing at Fraunhofer IZFP: Highlights and experiences of more than 3 decades of research. 24.-26.09.2017, Dresden, B. Wolter, K. Szielasko, R. Tschuncky, C. Conrad (eds.), Fraunhofer Publica, 2017, on CD

20. Forschungsvereinigung Antriebstechnik e.V.: Schulungsunterlage Barkhausenrauschprüfung - Version 01. Erstellt von der Arbeitsgruppe FVA 594 I „Barkhausenrauschen", 2011

21. Sackmann, D.; Heinzel, J.; Karpuschewski, B.: An approach for a reliable detection of grinding burn using the Barkhausen noise multi-parameter analysis. Procedia CIRP 87 (2020), pp. 415-419, DOI:10.1016/j.procir.2020.02.076

22. ISO 14104 : 2017-04: Gears - Surface temper etch inspection after grinding, chemical method, Beuth Verlag, Berlin, 2017

23. Sackmann, D.; Karpuschewski, B.; Epp, J.; Jedamski, R.: Detection of surface damages in ground spur gears by non-destructive micromagnetic methods. Forschung im Ingenieurwesen 83 (2019) 3, pp. 563-570, DOI:10.1007/s10010-019-00368-Z

24. Bausch, T.: Innovative Zahnradfertigung - Verfahren, Maschinen und Werkzeuge zur kostengünstigen Herstellung von Zahnrädern mit hoher Qualität. 4. Aufl., expert verlag GmbH, Renningen, 2011. - ISBN: 978-3816929086

\section{Bibliography}

DOI:10.1515/htm-2020-0001

HTM J. Heat Treatm. Mat.

76 (2021) 1; page 5-18

( 2021 Walter de Gruyter GmbH, Berlin/Boston, Germany

ISSN 1867-2493, e-ISSN 2194-1831 
The following discussion ensued/Folgende Diskussion ergab sich im Anschluss

Chairman: Thank you very much, Mr Sackmann, for the interesting lecture. On the cross-sections we have just seen, the retained austenite fractions were almost identical (Editor's note: see picture 5). Is there an influence on the signal height, meaning, is there an influence of the retained austenite content on the signal height that you determined?

D. Sackmann: We actually have contradictory results in our company and also within various projects. Sometimes we can establish a direct connection between the retained austenite and the signal height of the Barkhausen noise, sometimes not. What I can say about the results shown today: The retained austenite content is relatively identical regardless of the machining the material has seen. That means, within this series of experiments, the retained austenite content has no significant effect on the Barkhausen noise. Since the retained austenite is a paramagnetic phase, in theory it basically has an influence on the signal level. As I said, we cannot always show this influence explicitly. This is actually contradictory and can be justified by interactions with other influencing variables, which in turn influence the Barkhausen noise.

Chairman: Okay, and the two case-hardening depths you chose, i. e. $1 \mathrm{~mm}$ and $2.2 \mathrm{~mm}$, were they chosen purely by chance?

D. Sackmann: These are values that correspond to a standard industrial heat treatment (case-hardening) and are used by our industrial partners, among others.
Chairman: Vielen Dank, Herr Sackmann, für den schönen Vortrag. Auf den Schliffbildern, die wir gerade gesehen haben, waren die Restaustenitanteile annähernd identisch (Anm. d. R.: s. Bild 5). Gibt es einen Einfluss auf die Signalhöhe, das heißt, gibt es einen Einfluss des Restaustenitgehalts auf die Signalhöhe, die Sie ermittelt haben?

D. Sackmann: Da haben wir in unserem Hause und auch innerhalb verschiedener Projekte tatsächlich widersprüchliche Ergebnisse. Teilweise können wir einen direkten Zusammenhang zwischen dem Restaustenit und der Signalhöhe des Barkhausenrauschens herstellen, teilweise wiederum nicht. Was ich zu den heute gezeigten Ergebnissen sagen kann: Der Restaustenitgehalt ist unabhängig von der Bearbeitung, die das Material gesehen hat, relativ identisch. Das heißt innerhalb dieser Versuchsreihe hat der Restaustenitgehalt keinen signifikanten Einfluss auf das Barkhausenrauschen. Da der Restaustenit eine paramagnetische Phase ist, hat er in der Theorie grundsätzlich einen Einfluss auf die Signalhöhe. Wie gesagt können wir diesen Einfluss nicht immer explizit darstellen. Das ist tatsächlich widersprüchlich und kann durch Wechselwirkungen mit anderen Einflussgrößen, die das Barkhausenrauschen ihrerseits beeinflussen, begründet werden.

Chairman: Okay, und die zwei Einsatzhärtetiefen, die Sie gewählt haben, also $1 \mathrm{~mm}$ und 2,2 $\mathrm{mm}$, waren die rein zufällig gewählt?

D. Sackmann: Das sind Werte, die durchaus einer industrieüblichen Wärmebehandlung (Einsatzhärtung) entsprechen und so unter anderem von unseren Industriepartnern genutzt werden. 